\title{
Pattern Formation in the Basilar Papilla: Evidence for Cell Rearrangement
}

\author{
Richard Goodyear and Guy Richardson \\ School of Biological Sciences, University of Sussex, Falmer, Brighton, BN1 9QG, United Kingdom
}

The avian basilar papilla is composed of hair and supporting cells arranged in a regular pattern in which the hair cells are surrounded and isolated from each other by supporting cell processes. This arrangement of cells, in which the apical borders of hair cells do not contact one another, may be generated by contact-mediated lateral inhibition. Little is known, however, about the way in which hair and supporting cells are organized during development. Whole mounts double-labeled with antibodies to the $275 \mathrm{kDa}$ hair-cell antigen and the tight junction protein cingulin were therefore used to examine the development of cell patterns in the basilar papilla. Hair cells that contact each other at their apical borders are seen during early development, especially on embryonic days (E) 8 and 9, but are no longer observed after E12. Hair and supporting cell patterns were analyzed in three different areas of the papilla at E9 and
E12. In two of these regions between E9 and E12, the ratio of supporting cells to hair cells does not change significantly, whereas there is an increase in both the number of supporting cells around each hair cell and the number of hair cells that each supporting cell contacts. In the third region examined, there is a dramatic rise in the number of supporting cells around each hair cell, which although accompanied by a small, significant increase in the ratio of supporting cells to hair cells cannot be accounted for by an increase in supporting cell numbers. These data show that a rearrangement of hair and supporting cells with respect to one another may be a fundamental process underlying the development of a regular pattern in the basilar papilla.

Key words: ear; internal; cochlea; lateral inhibition; lateral specification; hair cell; supporting cell
The avian auditory organ, the basilar papilla, has been reported to contain $\sim 10,000$ hair cells (Tilney et al., 1986) that are organized, together with the supporting cells, into a highly regular mosaic. Each hair cell is surrounded by six or seven supporting cells, and each supporting cell, with the exception of those at the edge of the epithelium, contacts two or three hair cells (Corwin et al., 1991). The observation that hair cells do not contact one another at their apical borders, together with the highly organized nature of this epithelium, has prompted the suggestion that the regular cellular mosaic is generated by lateral inhibition. Hair cells may arise from a homogenous population of postmitotic cells through competition with their neighbors, with those that are prevented from becoming hair cells differentiating into supporting cells (Cotanche, 1987; Corwin et al., 1991; Lewis, 1991).

The concept of lateral inhibition was originally developed to explain how two initially equivalent neighboring cells acquire different fates, and in Drosophila is known to involve the neurogenic genes notch and delta (Muskavitch, 1994; ArtavanisTsakonas et al., 1995). One notable example of lateral inhibition is in the insect endoderm (Tepass and Hartenstein, 1995), where Notch-Delta signaling may result in the production of evenly spaced midgut-precursor cells in a field of interstitial cell precursors. The midgut-precursor cells are separated from each other by a single cell diameter in all directions, giving a pattern that is

Received December 30, 1996; revised May 16, 1997; accepted May 27, 1997.

This work was funded with grants from The Wellcome Trust and the Medical Research Council. We thank Laura Perry, Cecylia Malenczak, and Julian Thorpe for their excellent technical help, and Karen Nilsen for her assistance with the graphs. Thanks are also due to Kevin Legan and Ian Russell for their critical comments on this manuscript.

Correspondence should be addressed to Dr. Richard Goodyear, School of Biological Sciences, University of Sussex, Falmer, Brighton, BN1 9QG, UK.

Copyright (C) 1997 Society for Neuroscience $0270-6474 / 97 / 176289-13 \$ 05.00 / 0$ comparable to that of hair and supporting cells in the papilla. Highly conserved homologs of Notch and Delta have been identified in several vertebrate species, including chick, mouse, and frog (for review, see Nye and Kopan, 1995; Simpson, 1995; Lewis, 1996), and recent data indicate that Notch and Delta may have a role in vertebrate neurogenesis similar to that in Drosophila (Austin et al., 1995; Chitnis et al., 1995; Henrique et al., 1995; Lindsell et al., 1995).

Models incorporating lateral inhibition can successfully generate perfectly regular mosaics of hair and supporting cells from a hexagonally packed array of undetermined cells, providing differentiation initiates from a single seeding site (Goodyear et al., 1995). The simplicity of the basilar papilla relative to its mammalian counterpart the organ of Corti, the regularity of the mature cellular mosaic, the availability of molecular markers for the two cell types (Richardson et al., 1990; Bartolami et al., 1991; Goodyear et al., 1995, 1996), and the cloning of chick neurogenic genes (Henrique et al., 1995; Myat et al., 1996) make this organ a highly suitable structure for the study of cell-cell signaling mechanisms in vertebrate development. It is not known, however, how hair and supporting cells are arranged in the embryonic papilla, and a more thorough understanding of the way in which this cellular mosaic forms will help validate the models that have been proposed (Corwin et al., 1991; Lewis, 1991; Goodyear et al., 1995; Collier et al., 1996). Therefore, the aim of this study was to examine the patterns generated by the apical surfaces of cells in the basilar papilla during development, from the first appearance of hair cells through the formation of an organized mosaic.

\section{MATERIALS AND METHODS}

Tissue collection. Chicken eggs of the Isa Brown variety were incubated at $37^{\circ} \mathrm{C}$ in a humid incubator for between 6 and $18 \mathrm{~d}$. Whole heads from embryos of embryonic day (E) 10 and earlier and pieces of cartilaginous 
skull containing the inner ear from older embryos and early posthatch chicks were fixed in $3.7 \%(\mathrm{v} / \mathrm{v})$ formaldehyde in $100 \mathrm{~mm}$ sodium phosphate buffer, $\mathrm{pH} 7.2$, for $1 \mathrm{hr}$ at room temperature.

Preparation of double-labeled whole mounts. A fluorescent doublelabeling procedure was devised that allowed whole-mount preparations of the basilar papilla to be visualized with both anti-cingulin and antihair cell antigen (HCA) staining simultaneously through the fluorescein isothiocyanate (FITC) channel, and the anti-cingulin staining alone through the tetramethylrhodamine isothiocyanate (TRITC) channel. This method was particularly useful for identifying the contacts between adjacent cells and made it possible to identify hair cells unambiguously. Briefly, after three washes in PBS $(150 \mathrm{~mm}$ sodium chloride, $10 \mathrm{~mm}$ sodium phosphate, $\mathrm{pH}$ 7.2), the fixed cochlear ducts were dissected, and the tegmentum vasculosum overlying the basilar papilla was removed. Papillae were preblocked for $1 \mathrm{hr}$ with $10 \%$ (v/v) heat-inactivated horse serum (HS) in Tris-buffered saline (TBS) (150 mM sodium chloride, 10 mM Tris- $\mathrm{HCl}, \mathrm{pH} 7.4$ ) containing $0.1 \%$ Triton $\mathrm{X}-100$ (TX), and then incubated overnight in TBS/HS/TX containing monoclonal anti-HCA hybridoma supernatant (anti-HCA mAb) at a dilution of 1:100 and rabbit anti-cingulin serum (a gift from Sandra Citi, Dipartimento di Biologia, Universitá di Padova, Padova, Italy) (Citi et al., 1988) diluted 1:500. After 10 washes in TBS/HS/TX, papillae were incubated for $2 \mathrm{hr}$ in TBS/HS/TX containing a mixture of TRITC and FITC-conjugated swine anti-rabbit Ig, each at a dilution of 1:100. After an additional five washes in TBS/HS/TX, papillae were incubated for $2 \mathrm{hr}$ in TBS/HS/TX containing FITC-conjugated rabbit anti-mouse Ig diluted 1:100. Papillae were washed an additional five times and then incubated for $2 \mathrm{hr}$ in TBS/HS/TX containing FITC-conjugated swine anti-rabbit Ig diluted 1:100. After a final five washes, each papilla was mounted in Tris-buffered glycerol (1 part $100 \mathrm{~mm}$ Tris-HCl, pH 8.0, 9 parts glycerol) containing $0.1 \%(\mathrm{w} / \mathrm{v}) p$-phenylenediamine using shims of suitable thickness to prevent squashing and distortion of the epithelium. Using the same method, some preparations were double-labeled with rabbit anti-cingulin and a monoclonal antibody that recognizes centrosome-associated material (our unpublished results).

Preparation of single-labeled whole mounts. Papillae were dissected as described above and preblocked in TBS/HS for $1 \mathrm{hr}$, followed by overnight incubation in anti-HCA mAb at a dilution of 1:100. After they were washed 10 times in TBS/HS, papillae were incubated for $2 \mathrm{hr}$ in TBS/HS containing FITC-conjugated rabbit anti-mouse Ig diluted to 1:100, washed five times, incubated for $2 \mathrm{hr}$ in TBS/HS containing FITCconjugated swine anti-rabbit Ig diluted to 1:100, and mounted as described above.

Preparation of tissue for electron microscopy. Embryonic papillae were fixed in $3.7 \%$ formaldehyde and $0.025 \%$ glutaraldehyde in $100 \mathrm{~mm}$

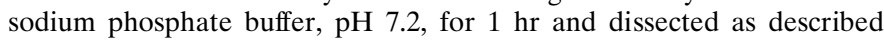
above. Papillae were preblocked for $2 \mathrm{hr}$ in TBS/HS, incubated overnight in anti-HCA mAb diluted 1:10 with TBS/HS, washed five times in TBS/HS, and incubated for $2 \mathrm{hr}$ in 10-nm-diameter colloidal goldconjugated rabbit anti-mouse Ig diluted 1:10 with TBS/HS that contained $0.05 \%(\mathrm{v} / \mathrm{v})$ Tween-20 and $1 \mathrm{~mm}$ EDTA (TBS/HS/Tween/EDTA). The samples were washed five times in TBS/HS/Tween/EDTA, five times in PBS (150 mM NaCl, $10 \mathrm{~mm}$ sodium phosphate, $\mathrm{pH}$ 7.2), fixed for $1 \mathrm{hr}$ with $1 \%(\mathrm{w} / \mathrm{v})$ osmium tetroxide in $100 \mathrm{~mm}$ sodium cacodylate, $\mathrm{pH} 7.1$, and washed three times in cacodylate buffer. After dehydration through ethanol, papillae were equilibrated with propylene oxide and embedded in Polarbed 812 resin. Blocks were cured at $60^{\circ} \mathrm{C}$ for $24 \mathrm{hr}$. Semi- and ultrathin sections were cut on a Reichert Ultracut E microtome. Thin sections were mounted on copper grids, counterstained with $1 \%(\mathrm{w} / \mathrm{v})$ aqueous uranyl acetate and lead citrate (Reynolds, 1963), and examined using a Hitachi 7100 transmission electron microscope.

Quantitative analysis. The total numbers of hair cells in embryonic papillae were counted from photomontages of HCA-stained preparations that had been photographed with a $16 \times$ objective and printed at a final magnification of $215 \times$. Data were obtained from seven papillae from E6, seven from E7, seven from E8, two from E9, three from E9.5, and three from E12. Hair cell-hair cell contacts, the numbers of hair cells contacting each supporting cell, and the numbers of supporting cells around each hair cell were analyzed from micrographs of cingulin/HCA doublelabeled whole mounts that had been photographed at a primary magnification of $100 \times$ under oil immersion and printed at a final magnification of $2000 \times$. To quantitate hair cell-hair cell contacts, 132 randomly selected areas of fixed size were photographed in the proximal, medial, and distal thirds of the papillae from E8, E9, E11, E12, and E15 embryos. The numbers of pairs of contacting hair cells were expressed as a

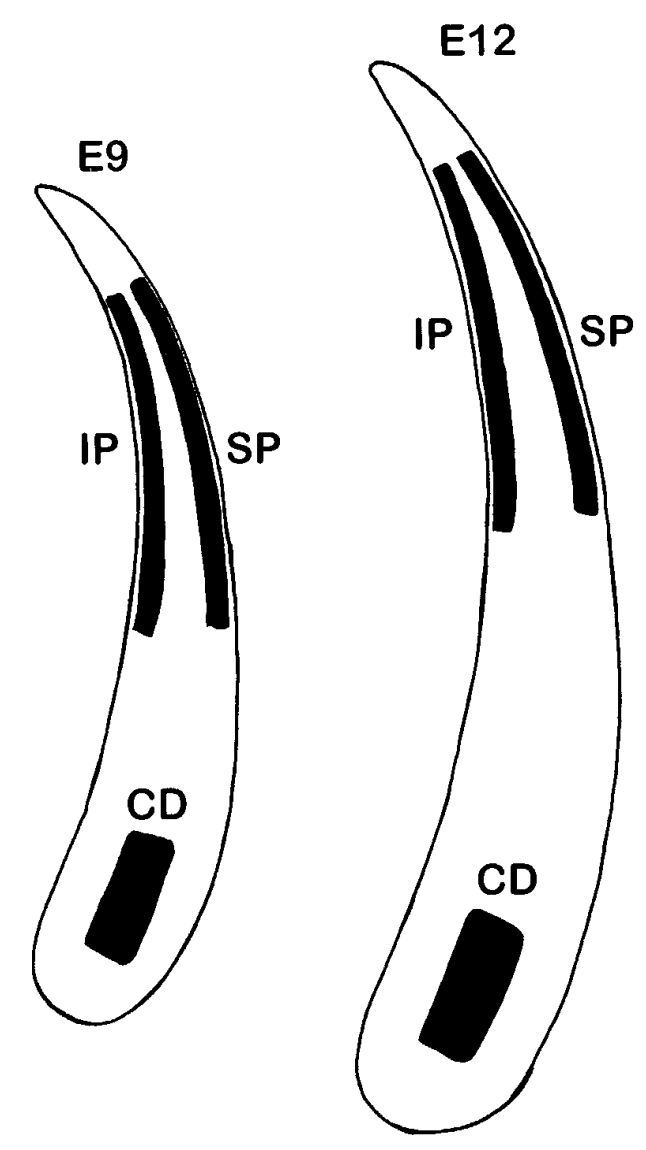

Figure 1. Schematic drawings of E9 and E12 chick basilar papillae. Figure shows the three regions within which micrographs were taken for the analysis of contacts between hair and supporting cells. IP, Inferiorproximal; $S P$, superior-proximal; $C D$, central-distal.

percentage of the total number of hair cells in each area, and the average of the number of contacting pairs was determined for each third of the papilla at each stage. To quantitate the average number of supporting cells around each hair cell and the average number of hair cells that each supporting cell contacts in the central-distal, inferior-proximal, and superior-proximal regions of the papilla (Fig. 1), the number of hair cells contacting each supporting cell and the number of supporting cells around each hair cell were counted in randomly selected areas from within each region. Data were obtained with six papillae from four E9.25 embryos and seven papillae from four E12 embryos. Between 17 and 28 areas from each of the three different regions were counted for the two stages, and the averages were determined. Care was taken during the analysis not to include cells that lie beyond the inferior and superior thirds of the basilar papilla for the inferior-proximal and superiorproximal counts, respectively. A total of 7280 hair cells were analyzed to determine the averages for the number of supporting cells around each hair cell in the three different regions, and 15,632 supporting cells were analyzed to determine the averages for the numbers of hair cells that each supporting cell contacts. The ratios of supporting cells to hair cells were estimated from fixed areas (either $6 \times 8 \mathrm{~cm}, 8 \times 8 \mathrm{~cm}$, or $10 \times 10$ $\mathrm{cm}$ on the micrographs) in each of the three regions at both stages using the same set of micrographs that were used for determining the hair and supporting cell contacts. A total of 4877 hair cells and 11,563 supporting cells were counted to determine these ratios. Differences between means were tested for significance using Student's $t$ test, with $p<0.05$ taken as the criterion for statistical significance.

\section{RESULTS}

\section{Hair cell differentiation during early development}

Hair cells can first be identified with HCA staining after $6 \mathrm{~d}$ of incubation (E6); they lie within a small, roughly circular patch at 


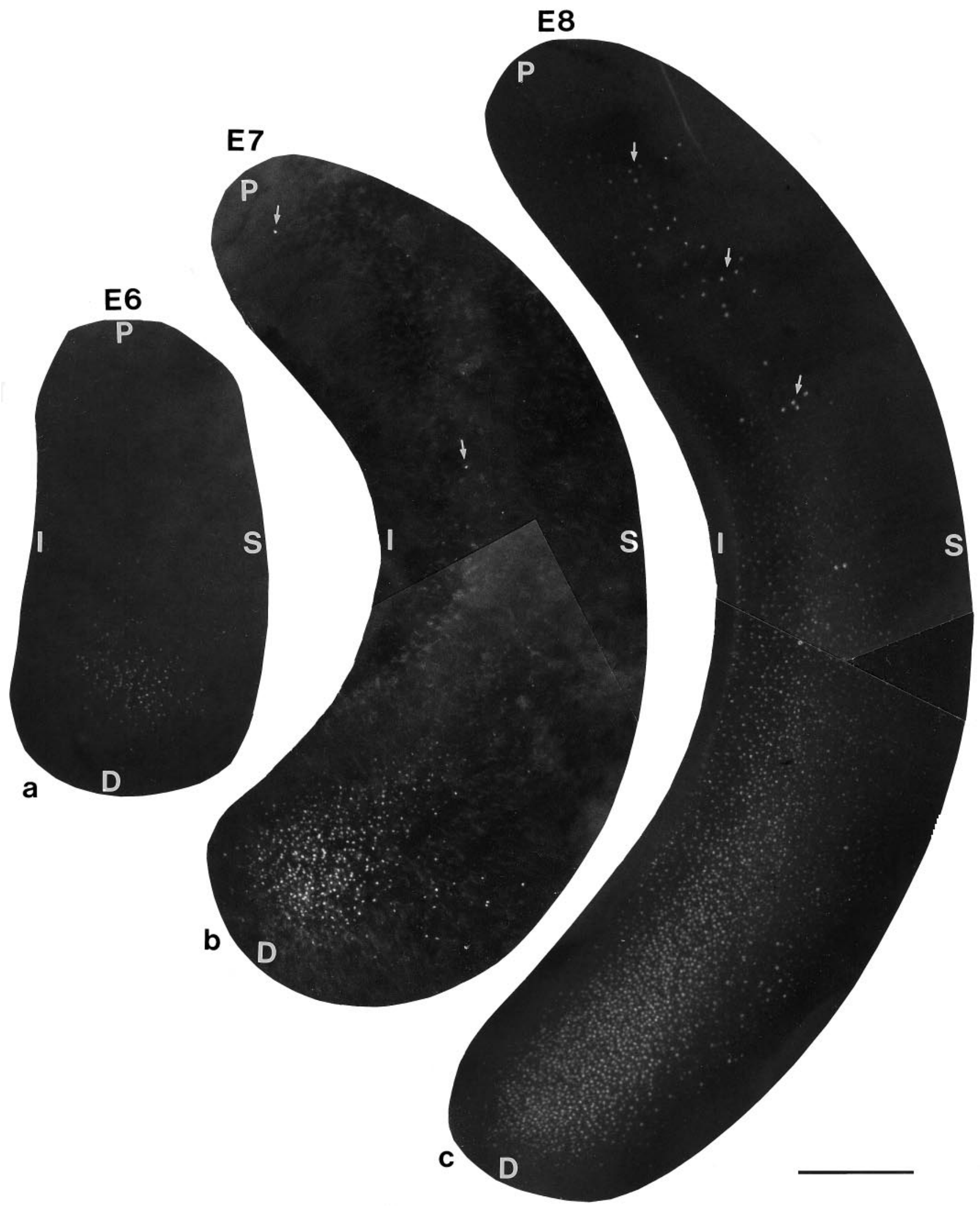

Figure 2. Basilar papillar whole mounts stained with antibodies to the HCA. At E6 ( $a$ ), hair cells are seen in a small patch at the distal end of the papilla. By E7 $(b)$, the patch has enlarged and a few proximally located hair cells (arrows) can also be observed. Hair cells are seen along the entire length of the papilla at E8 (c), although those seen at the proximal end (arrows) are stained more brightly and appear distinct from the remainder. $D$, Distal; $P$, proximal; $I$, inferior; $S$, superior. Scale bar, $100 \mu \mathrm{m}$ (applies to all micrographs). 


\section{DISTAL}
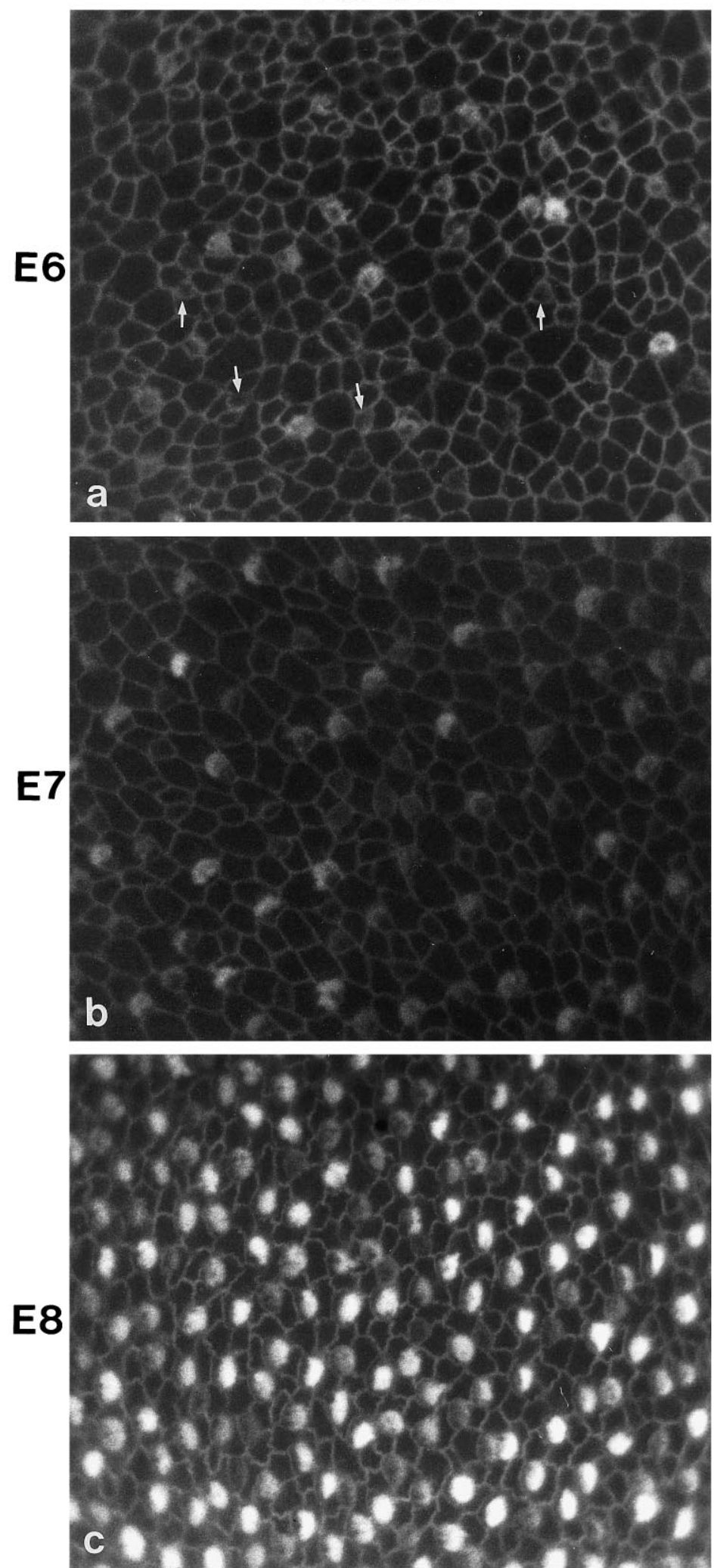

\section{PROXIMAL}
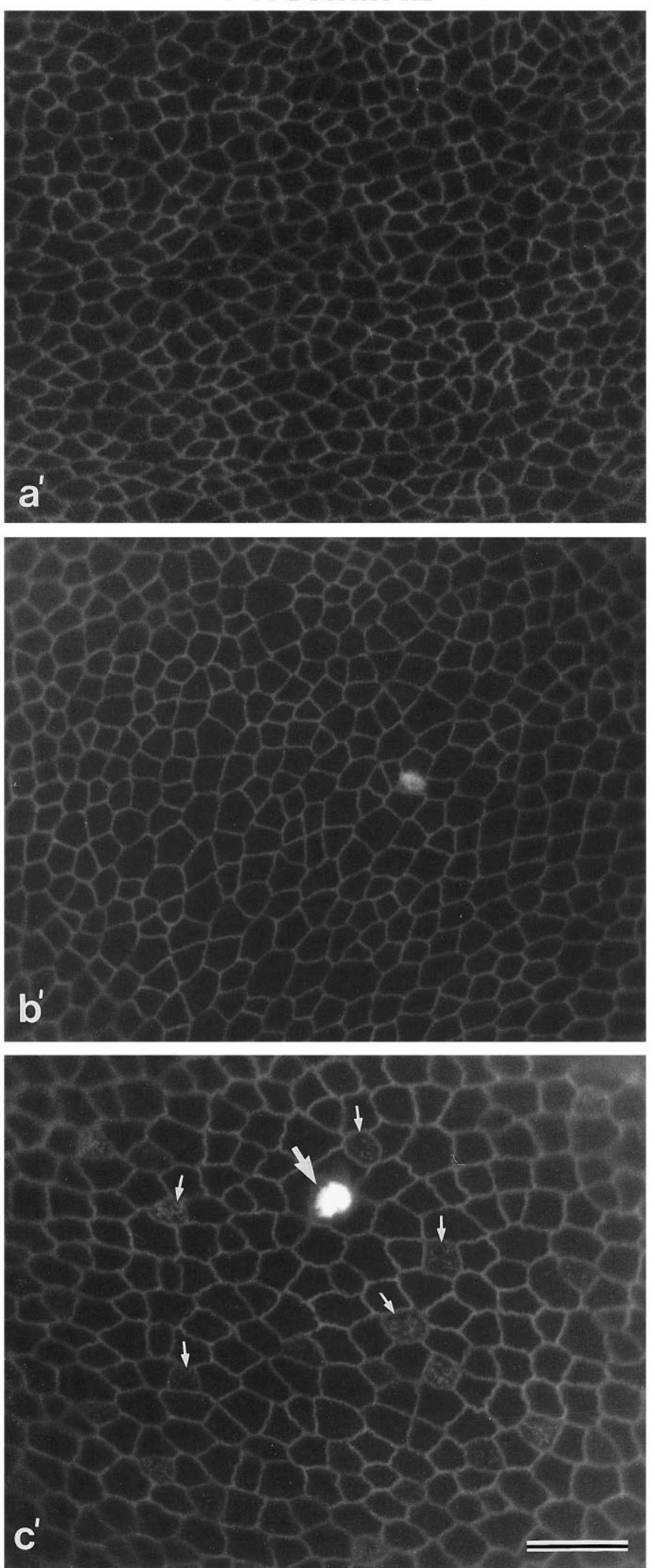

Figure 3. Anti-HCA and cingulin staining in the early embryonic basilar papilla. Micrographs are from distal $(a-c)$ and proximal $\left(a^{\prime}-c^{\prime}\right)$ regions of E6 $\left(a, a^{\prime}\right)$, E7 $\left(b, b^{\prime}\right)$, and E8 $\left(c, c^{\prime}\right)$ papillae that have been stained with antibodies to both the HCA and cingulin. At E6, many distal cells stain only very weakly for the HCA (arrows in $a$ ). At E7 an increasing number of hair cells are seen in the distal region $(b)$ and the first proximally located hair cells are seen at this stage $\left(b^{\prime}\right)$. At E8, in distal regions, the density of hair cells is very high, and the epithelium has a compact, crowded appearance $(c)$. In the proximal end at this stage $\left(c^{\prime}\right)$, many hair cells are only just starting to differentiate (small arrows), but a small number appear to be much more mature (large arrow). Scale bar (located in $\left.c^{\prime}\right): 10 \mu \mathrm{m}$ (applies to all micrographs). 


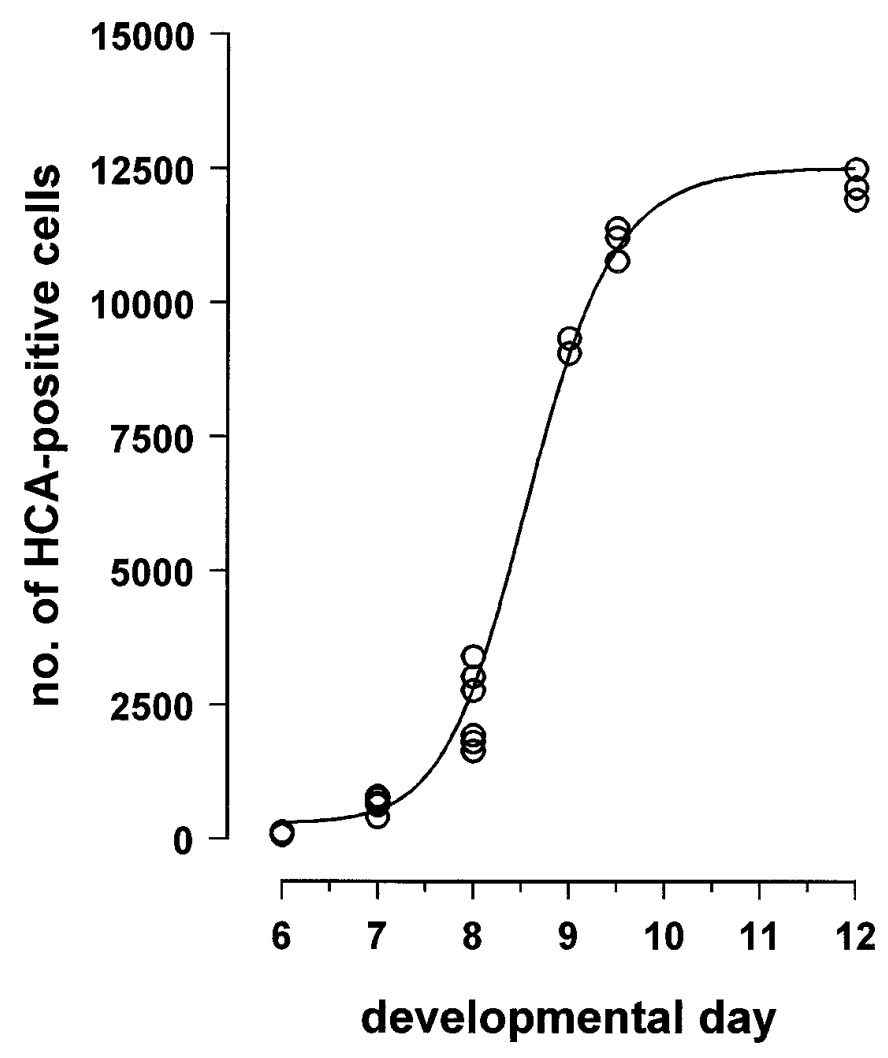

Figure 4. Graph of changes in number of HCA-positive cells observed in photomontages of the basilar papilla with developmental age. The number of HCA-positive hair cells increases most rapidly between E7.5 and E9.5. The means \pm SE for each stage are as follows: E6, $94 \pm 7.3(n=7)$; $\mathrm{E} 7,627 \pm 50.1(n=7) ; \mathrm{E} 8,2453 \pm 253.4(n=7) ; \mathrm{E} 9,9200 \pm 140.0(n=$ 2); E 9.5, 11,129 $\pm 181.4(n=3)$; and E12, 12,192 $\pm 165.0(n=3)$.

the distal end of the papilla (Fig. $2 a$ ). These hair cells tend to be fairly scattered and are usually separated by several HCAnegative cells (Fig. 3a). HCA-positive cells are not seen in the proximal end of the papilla at E6 (Figs. $2 a, 3 a^{\prime}$ ). At the beginning of E7, $24 \mathrm{hr}$ later, the distal patch of hair cells is larger and extends further proximally (Fig. 2b). Hair cells in the distal region of the papilla at E7 appear to be more evenly spaced than at E6 (Fig. 3a,b). A small number $(<10)$ of more brightly stained hair cells is observed at E7 that are separate from the distal patch and lie within the proximal end of the basilar papilla (Figs. $2 b$, $\left.3 b^{\prime}\right)$. With the exception of these brightly stained cells, HCApositive cells are not observed in the proximal end of the papilla at this stage (Fig. $\left.3 b^{\prime}\right)$. By E8, hair cells are seen throughout the papilla, although the majority are still concentrated in the distal region (Fig. $2 c$ ) where the epithelium has a crowded appearance (Fig. $3 c$ ). Up to 50 brightly stained hair cells are observed in the proximal region at E8 (Fig. 2c), and cells staining weakly for the HCA are seen close to these bright cells (Fig. $3 c^{\prime}$ ). At these early stages of development the cellular mosaic is not a regular hexagonally packed array, with cells contacting as few as three or as many as eight other cells at their apical borders (Fig. 3).

The number of HCA-positive hair cells in the basilar papilla increases rapidly between E7.5 and E9.5 (Fig. 4). The distal patch observed at E6 contains 100 HCA-positive hair cells. This increases to between 400 and 800 at E7, and by E9.5 11,100 are visible throughout the epithelium. At E12, there are 12,200 HCApositive hair cells in the papilla (Fig. 4). It should be noted that the number of HCA-positive hair cells determined from whole mounts photographed at $16 \times$ is likely to be an underestimate for all stages before E12, because weakly staining, newly emerging hair bundles are not detected at this magnification. At E12, when all of the hair cells in the papilla stain brightly, the number of HCA-positive hair cells observed is likely to be an accurate estimate of the number of differentiated hair cells present in the papilla. The number of hair cells at E12 is nearly 2000 more than that determined by Tilney et al. (1986) at this stage, possibly because of the different methods used.

\section{Apical contacts between differentiating hair cells}

Pairs of contacting hair cells are seen throughout the basilar papilla at E8 but decrease in frequency thereafter. Figures 5-7 illustrate typical views of the epithelial surface from the centraldistal (Fig. 5), superior-proximal (Fig. 6), and inferior-proximal (Fig. 7) regions of the papilla at E9 and E12. Several examples of hair cell-hair cell contacts in the central-distal region of an E9 papilla are shown in Figure 5a, $a^{\prime}$. Transmission electron microscopy of HCA-labeled papillae confirms that pairs of hair cells do come into direct physical contact at their apical borders (Fig. $8 a-c)$. Quantitative analysis of hair cell-hair cell contacts was based on data obtained from the proximal, medial, and distal thirds of the papilla. No distinction was made between the inferior and superior regions of the papilla for this part of the study. This analysis indicates that the highest frequency of hair cell-hair cell contacts occurs in the distal third of the papilla, and this reduces proximally (Fig. 9). By E9, contacting hair cells are not seen in the proximal third of the papilla (Figs. 6, 7, 9), and the numbers seen in the medial third are reduced in comparison to E8 (Fig. 9). By E12, contacting pairs of hair cells are rarely seen in the distal third of the papilla and are entirely absent elsewhere (Figs. 5-7, 9). By E15, contacting hair cells are no longer observed in the distal region (Fig. 9). Where examples of hair cell-hair cell contacts are seen, one or both of the cells involved generally stain noticeably less brightly than nearby isolated hair cells (Fig. 5a, Table 1).

\section{Arrangements of hair and supporting cells at E9 and $\mathrm{E12}$}

The arrangement of hair and supporting cells changes dramatically between E9, after the great majority cells in the basilar papilla have withdrawn from the cell cycle (Katayama and Corwin, 1989), and E12, before the surfaces of supporting cells begin to compress (Figs. 5-7) but when the pattern resembles that seen in the mature papilla (data not shown). To determine the extent to which the organization is changing between these two stages, the average number of supporting cells around each hair cell and the average number of hair cells that each supporting cell contacts need to be determined; however, the analysis of how hair and supporting cells are arranged at different developmental stages is complicated by two factors. First, the number of supporting cells around each hair cell is not consistent throughout the papilla (Fig. 10a); second, the arrangement of hair and supporting cells begins to change before all the HCA-positive cells have appeared (Fig. 4). To circumvent these problems we selected three relatively mature regions of the papilla and analyzed them independently. These areas were a central region of the distal papilla and a superior region of the proximal papilla, both of which contain just tall hair cells, and an inferior region of the proximal papilla, which is composed solely of short hair cells (SHCs) (Tanaka and Smith, 1978) (Fig. 1). Although the number of HCA-positive hair 

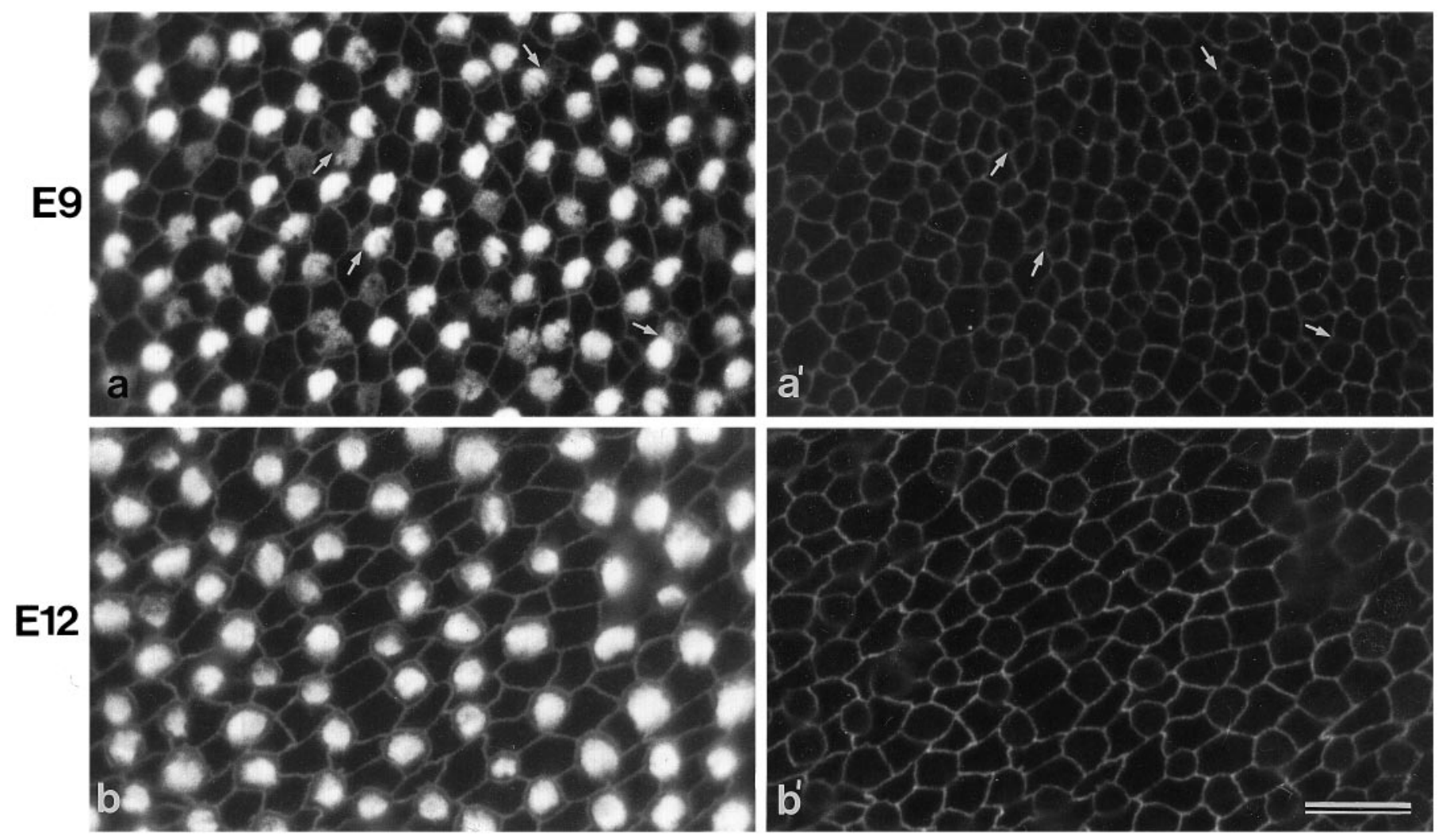

Figure 5. Whole mounts from the central-distal papilla at E9 and E12. Preparations have been double-labeled to reveal HCA and cingulin through one channel $(a, b)$ and cingulin alone through the other channel $\left(a^{\prime}, b^{\prime}\right)$. Note the presence of hair cell-hair cell contacts $($ arrows $)$ at E9 $\left(a^{\prime}, a^{\prime}\right)$. These are extremely infrequent by E12 $\left(b^{\prime}, b^{\prime}\right)$. The overall appearance of the papilla does not change overtly between E9 and E12 in this region. Scale bar (shown in $\left.b^{\prime}\right): 10 \mu \mathrm{m}$ (applies to all micrographs).

cells appears to increase quite substantially between E9 and E12 (Fig. 4), the actual number of cells that differentiate between these two stages is likely to be considerably less than shown in Figure 4, because the method used to determine these numbers does not detect the newly emerged, weakly stained hair cells (see above). These weakly stained hair cells are observed mostly around the periphery of the distal half of the papilla [the region where almost all tritium-labeled hair cells are observed after injection of ${ }^{3} \mathrm{H}$ thymidine on E8.5 (Katayama and Corwin, 1989)] and in very small numbers at its extreme proximal tip (data not shown). These areas, where weakly HCA-positive hair cells are observed at E9.5, were deliberately excluded from our study. The data of Katayama and Corwin (1989) indicate that cells in the central-distal and superior-proximal regions are all produced by E7, whereas $>99 \%$ of those in the entire proximal two-thirds of the papilla (within which the inferior-proximal region is located) are produced between E7 and E8.5. To determine whether either hair or supporting cells were being either added to or lost from these regions between $\mathrm{E} 9$ and $\mathrm{E} 12$, we calculated the ratio of hair and supporting cells within each area, in addition to determining the number of supporting cells around each hair cell and the number of hair cells that each supporting cell contacts. Furthermore, to confirm that each cingulin-demarcated supporting cell process is derived from an individual cell, as opposed to being one of several processes projecting from a single cell, epithelia were double-labeled with a monoclonal antibody to centrosome-associated material and rabbit anti-cingulin antibodies. These preparations clearly show that each cingulindemarcated surface contains a single centrosome (Fig. 10b, $b^{\prime}$ ) and therefore indicate that the numbers of these profiles can be used to determine how many supporting cells surround the apical border of each hair cell.

The average numbers of supporting cells around each hair cell and the average numbers of hair cells that each supporting cell contacts at E9 and E12 in the three different regions are presented in Figure 11. In all three regions the average number of supporting cells around each hair cell (Fig. 11a,c,e) and the average number of hair cells that each supporting cell contacts (Fig. $11 b, d, f)$ both increase. These increases are all statistically significant (Table 2), but are only readily noticeable in cingulin/HCA double-labeled whole mounts in the inferior-proximal region (Fig. 7) and not in the central-distal (Fig. 5) or superior-proximal (Fig. 6) areas. Staining of posthatch papillae with the antibody to centrosome-associated material shows that the high number of supporting cells seen around each hair cell in the inferiorproximal region at E12 persists to maturity of the papilla (Fig. $10 c)$. It should also be noted that a small number $(1.1 \%)$ of cells in the inferior-proximal region at E9 did not contact any hair cells (Fig. 7a). Such cells were only very rarely observed in the other regions and were not found anywhere by E12.

The average number of hair and supporting cells per 10,000 $\mu \mathrm{m}^{2}$ in the central-distal, superior-proximal, and inferiorproximal regions of the basilar papilla at E9 and E12 are shown in Table 3. The ratios of supporting cells to hair cells in the central-distal and superior-proximal regions of the papilla do not change between E9 and E12 and are not significantly different (Table 3). A small but statistically significant increase in the ratio 

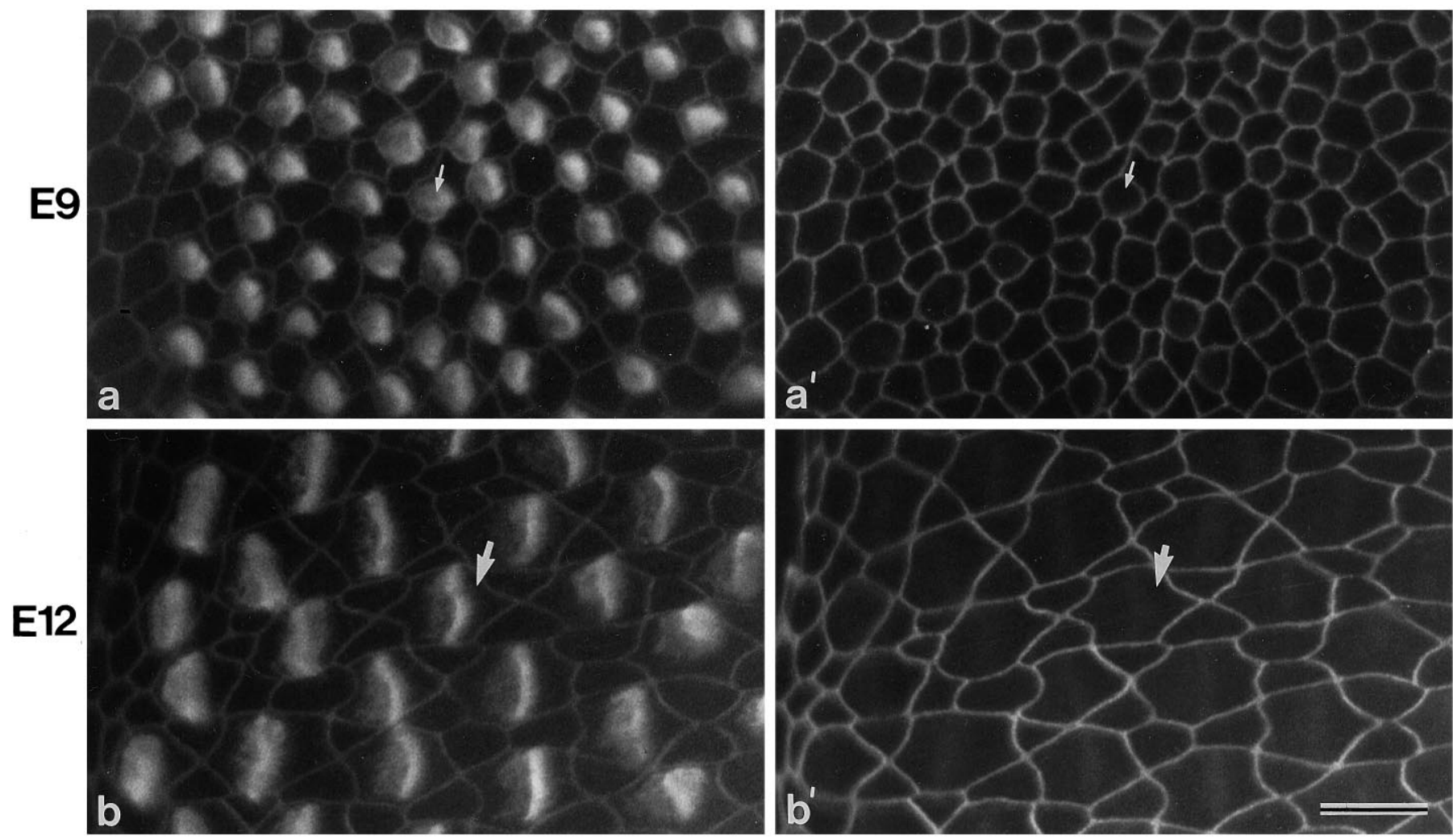

Figure 6. Whole mounts from the superior-proximal papilla at E9 and E12. Preparations have been double-labeled to reveal HCA and cingulin through one channel $(a, b)$ and cingulin alone through the other channel $\left(a^{\prime}, b^{\prime}\right)$. Small arrows in $a$ and $a^{\prime}$ point to the same hair cell. By E12 each hair cell is surrounded by a number of roughly triangle-shaped supporting cells in this region. Big arrows in $b$ and $b^{\prime}$ point to the same hair cell. Scale bar (shown in $\left.b^{\prime}\right): 10 \mu \mathrm{m}$ (applies to all micrographs).

of supporting cells to hair cells occurs between E9 and E12 in the inferior-proximal region (Table 3).

\section{DISCUSSION}

This study describes how the pattern of hair and supporting cells in the avian basilar papilla is generated during development, and it provides evidence that the regularity of the cellular mosaic may result partially from a rearrangement of the two cell types with respect to one another. In addition, both quantitative and qualitative descriptions of the very early stages of hair cell differentiation in the basilar papilla reveal a complex relationship between the timing of hair cell generation and the onset of overt cytodifferentiation, as defined by the onset of HCA expression.

\section{Hair cell differentiation is not directly linked to birthdate}

Both scanning electron microscope (Cotanche and Sulik, 1984) and immunofluorescent studies (Bartolami et al., 1991) have shown that hair cell differentiation begins in the distal end of the papilla at E6, and the results of this study confirm these earlier reports. The use of anti-HCA-stained whole mounts provides a way of globally examining this process. These preparations show that the distal patch of hair cells first observed at E6 extends proximally and expands across the width and along the length of the enlarging sensory epithelium over the course of $4 \mathrm{~d}$. In addition to the distally enlarging patch, however, a spatially separate scattering of brightly stained hair cells is observed in the proximal end of the papilla at E7. Hair cell differentiation in the papilla therefore does not simply proceed in a distal to proximal direction. The thymidine labeling study of Katayama and Corwin (1989) has reported that a longitudinal strip of cells running most of the length of the papilla first leaves the cell cycle between E5 and E6, and subsequent postmitotic cells are added peripherally, along the inferior edge of this strip proximally and all around it distally, until virtually the full complement has been born by E8.5. Because the differentiation of most hair cells tends to spread from the distal to the proximal end of the basilar papilla, similarly aged postmitotic cells do not all differentiate simultaneously. The lag between the time at which hair cells withdraw from the cell cycle and the onset of differentiation would appear to be longer for most of the proximal cells than it is for the distal cells. Hair cells at the distal end of the papilla have $<50$ stereocilia per bundle, whereas those at the proximal end have $>200$ (Tilney and Saunders, 1983), and it is possible that the larger stereociliary array with its associated HCA takes longer to initiate in the proximal than the distal end of the papilla. Alternatively, locally acting factors derived from newly differentiated hair cells may be required to stimulate the development of other hair cells in the papilla, which explains why there is a gradient of development along the epithelium. This implies, however, that the hair cells that first form in the distal patch on E6 and in the proximal end at E7 do not require such a factor. In this respect it is interesting to note that although the proneural function of Notch is required for neural differentiation in most of the photoreceptors in the developing Drosophila eye, those at the posterior and lateral margins of the eye where retinal differentiation begins do not require Notch function for neurogenesis (Baker and Yu, 1997). The presence of a general distal-proximal gradient of hair cell 

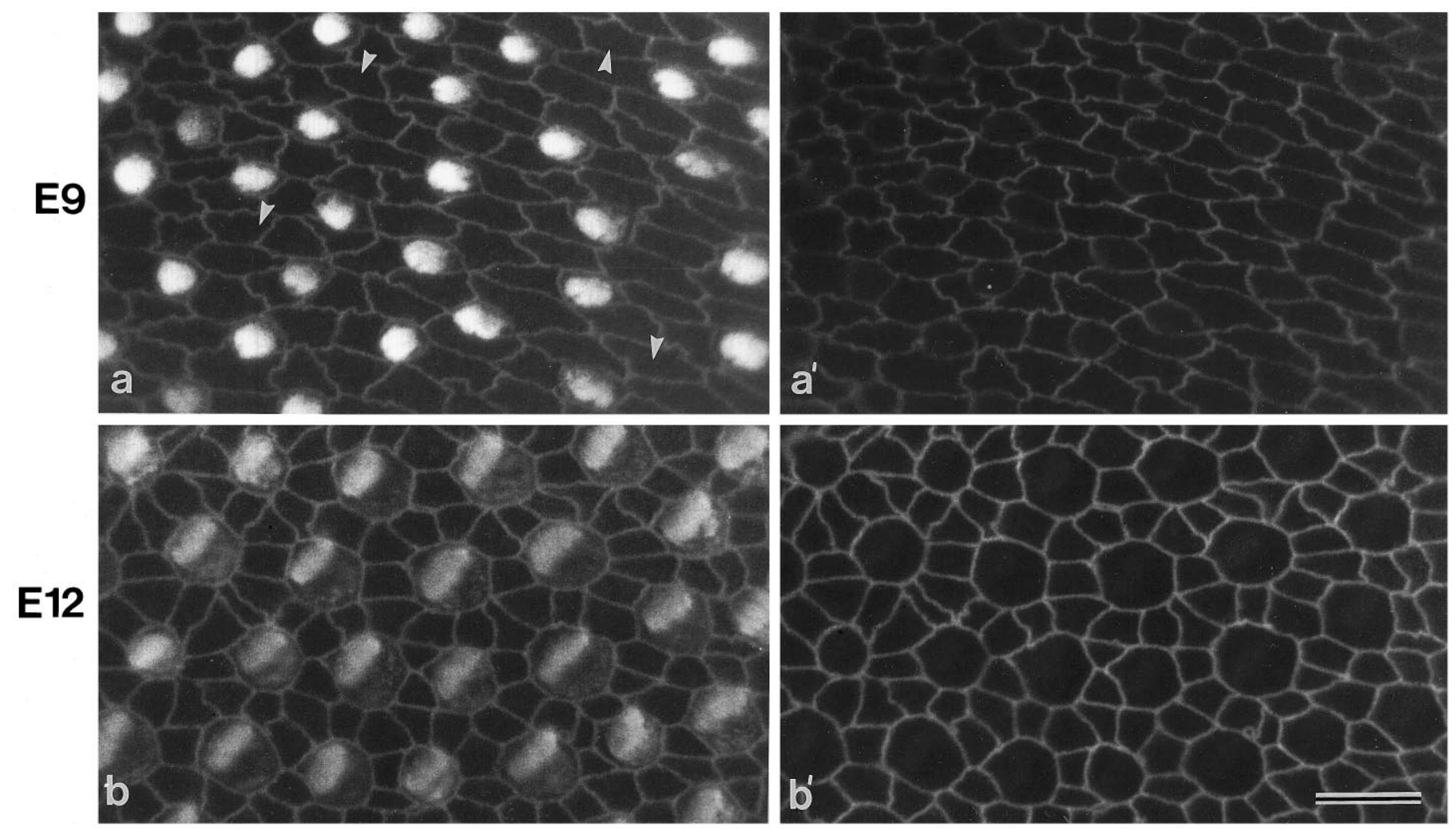

Figure 7. Whole mounts from the inferior-proximal papilla at E9 and E12. Preparations have been double-labeled to reveal HCA and cingulin through one channel $(a, b)$ and cingulin alone through the other channel $\left(a^{\prime}, b^{\prime}\right)$. At E9 $(a)$, some supporting cells do not contact any hair cells $($ arrowheads); at E12 $(b)$, virtually all supporting cells contact two or three hair cells. Note the large number of supporting cells around each hair cell at E12 compared with those at E9. Scale bar (shown in $b^{\prime}$ ): $10 \mu \mathrm{m}$ (applies to all micrographs).

differentiation in the chick basilar papilla, which is also paralleled by similar gradients in supporting cell differentiation (Goodyear et al., 1995, 1996) and BMP4 expression (Oh et al., 1996), does not correlate with any other known process. For example, the ingrowth of nerve fibers occurs along the entire length of the epithelium before the onset of hair cell differentiation (Bartolami et al., 1991).

\section{The mosaic is initially irregular and the hair cells are widely spaced}

Two aspects of the very early stages of papilla development are worth noting. First, when the first hair cells appear between E6 and E7, the apical surfaces of the cells vary considerably in their size, and individual cells can contact as few as three or as many as eight other cells. The cells are therefore not packed in a perfectly hexagonal array, as has been assumed in various models of hair and supporting cell differentiation (Goodyear et al., 1995; Collier et al., 1996). Furthermore, this also means that there are large differences in the lengths of contacting cell borders and thus the area of the contact sites between adjacent cells. If the strength of cell-cell signaling systems is proportional to membrane apposition area, then this variation needs to be considered in future models, and it will be interesting to see whether the different models proposed can be made to run on the patterns actually observed. The second point of interest concerns the distribution of the first hair cells that appear. These are usually widely spaced and separated by the processes of several other cells that are either undetermined cells or supporting cells. Such an observation would be consistent with hair cells that appear stochastically throughout a region of the epithelium as a consequence of a random fluctuation in the level of a signaling molecule, as in models based solely on lateral inhibition (Collier et al., 1996; R. Goodyear, http://139.184.160.76/model.html). The simultaneous appearance of widely spaced hair cells is not consistent with crystal growth models that incorporate a combination of both induction and lateral inhibition to generate hair cells and start from a single seed site, but it is compatible with those that use the same mechanism and initiate from multiple points (Goodyear et al., 1995).

\section{Transient hair cell-hair cell contacts are seen during development}

As a result of lateral inhibition, hair cells should not end up lying adjacent to one another in the epithelium; however, a computer simulation of basilar papilla formation based solely on lateral inhibition (R. Goodyear, http://139.184.160.76/model.html) predicts that two adjacent cells could both initially follow the hair cell pathway before one finally becomes dominant. In this respect, it is interesting to note that numerous hair cell-hair cell contacts are seen before E12, and often one of these cells stains noticeably weaker than the other for the HCA or both stain more weakly than the surrounding cells. Hair cells therefore do form side by side during early development, and the variation in staining intensity indicates that they may be competing with one another. The inhibited hair cell may either downregulate HCA expression and convert to a supporting cell phenotype or be eliminated by apoptosis. In a hypothetical field of 1000 cells in the central-distal region of the papilla at $\mathrm{E} 9$, where most of the hair cell-hair cell 

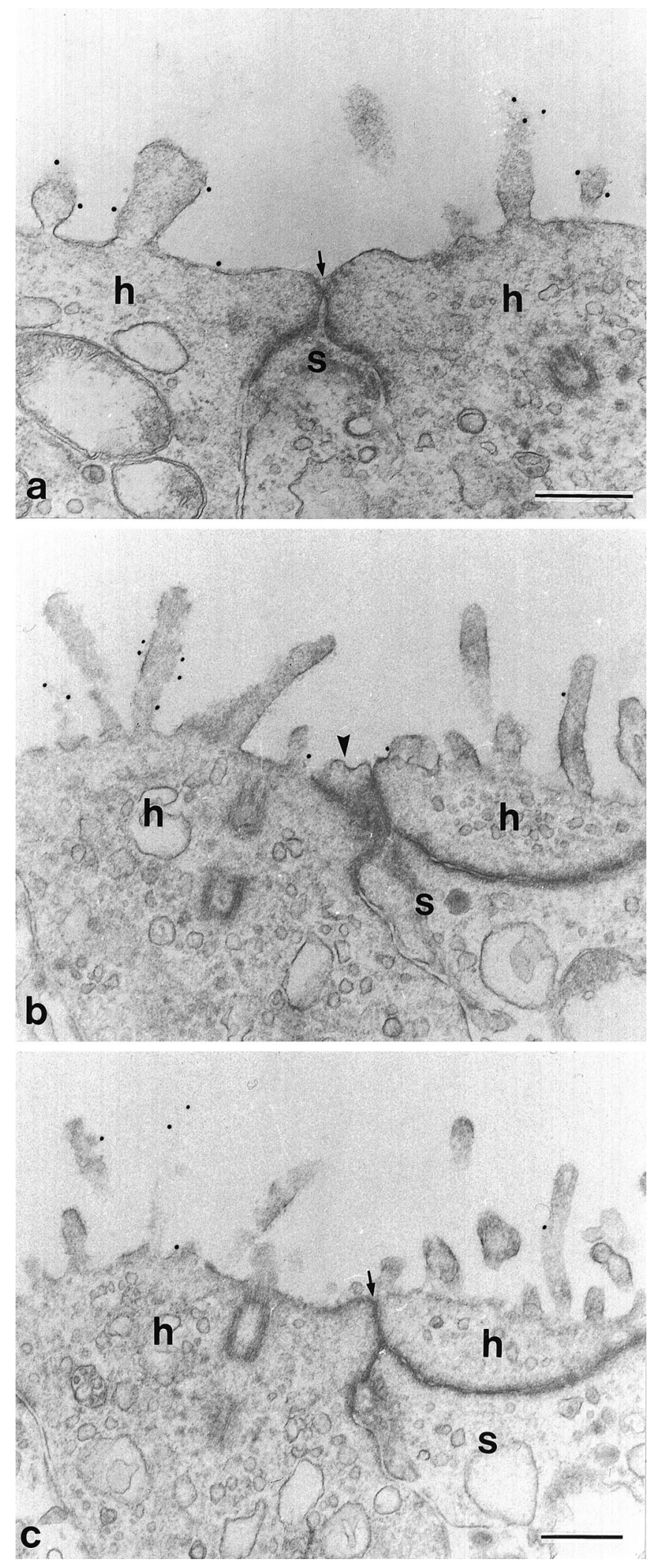

Figure 8. Electron micrographs of E10 papillae that have been colloidalgold labeled for the HCA. $a$, Two hair cells can be seen contacting at their apical border (arrow). $b, c$, Adjacent serial sections that show two goldlabeled hair cells separated by a supporting cell process (arrowhead in $b$ ), which come into contact at their apical ends (arrow in $c$ ). $h$, Hair cell; $s$, supporting cell. Scale bars: $500 \mathrm{~nm}$ (bar in $c$ also applies to $b$ ).

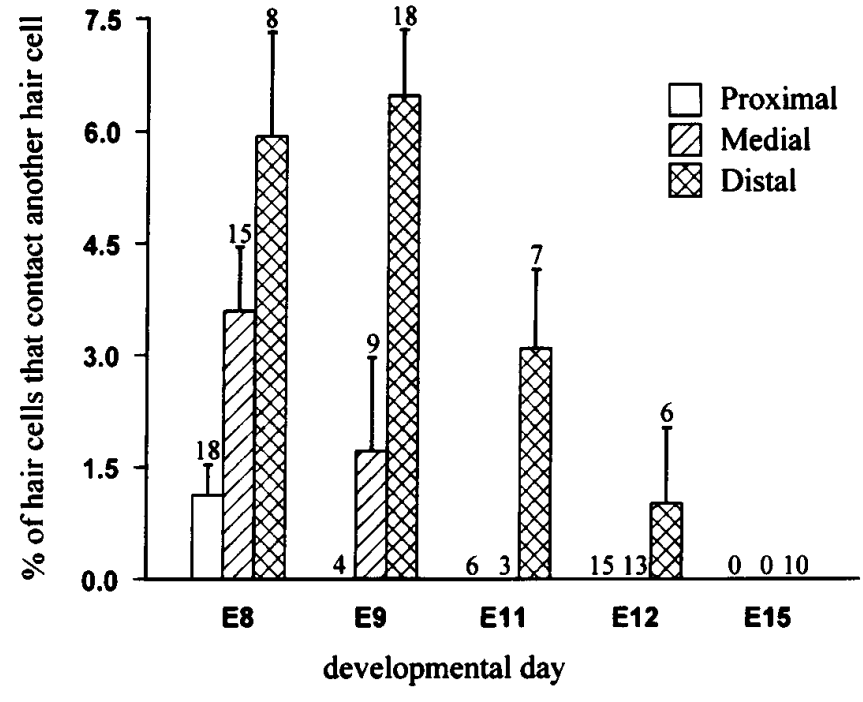

Figure 9. Graph showing how hair cell-hair cell contacts change during papillar development. Values for the proximal, medial, and distal regions at each stage are indicated. Values above bars are the number of areas examined for each region. Counts were not made from the medial and proximal regions of E15 papillae because of the high degree of compaction of the supporting cell apical surfaces in these areas. Error bars represent SDM.

\begin{tabular}{lcccc}
\hline Table 1. Staining patterns of contacting pairs of hair cells \\
& E8 & \multicolumn{1}{c}{ E9 } & E11 & E12 \\
\hline Both hair cells stain brightly & $1 / 41$ & $7 / 62$ & $5 / 11$ & $3 / 3$ \\
One or both hair cells stain weakly & $40 / 41$ & $55 / 62$ & $6 / 11$ & $0 / 3$
\end{tabular}

Table shows the change in the proportion of hair cell-hair cell contacts in which one or both hair cells stain weakly for the HCA. Note that in most cases during early (E8, E9) development, one or both of the hair cells stain weakly for the HCA, but by E12, in the few examples that are seen, both hair cells stain strongly for the HCA.

contacts are observed, with a supporting cell-hair cell ratio of $1.85: 1,350$ of the cells would be hair cells, and of these there would be 12 pairs contacting each other. If one hair cell in each pair was to convert to a supporting cell by E12, the ratio would increase to 1.96:1. Alternatively, if one hair cell in each pair was to die by E12, the ratio would increase to 1.92:1. These increases would be small $(<6 \%)$ and may not be apparent, but the data actually show a slight nonsignificant decrease in the ratio of supporting cells to hair cells between E9 and E12 in the centraldistal region, indicating that some other mechanism may be operating to eliminate hair cell-hair cell contacts. It is also interesting to note that as development proceeds the proportion of contacting pairs where both cells stain brightly increases (from 2.4 to $100 \%$ ). The numbers of hair cell pairs, however, are small at E12 and these may be the last few remaining pairs that will be eliminated, although lateral inhibition may no longer be functioning at this relatively late stage of development.

\section{Hair and supporting cells rearrange with respect to one another}

As the mosaic acquires regularity and hair cell-hair cell contacts are disappearing, the average number of supporting cells around each hair cell increases. In the central-distal and superior-inferior regions, the number of supporting cells around each hair cell increases without a statistically significant change in the ratio of supporting cells to hair cells, and previous data (Katayama and 

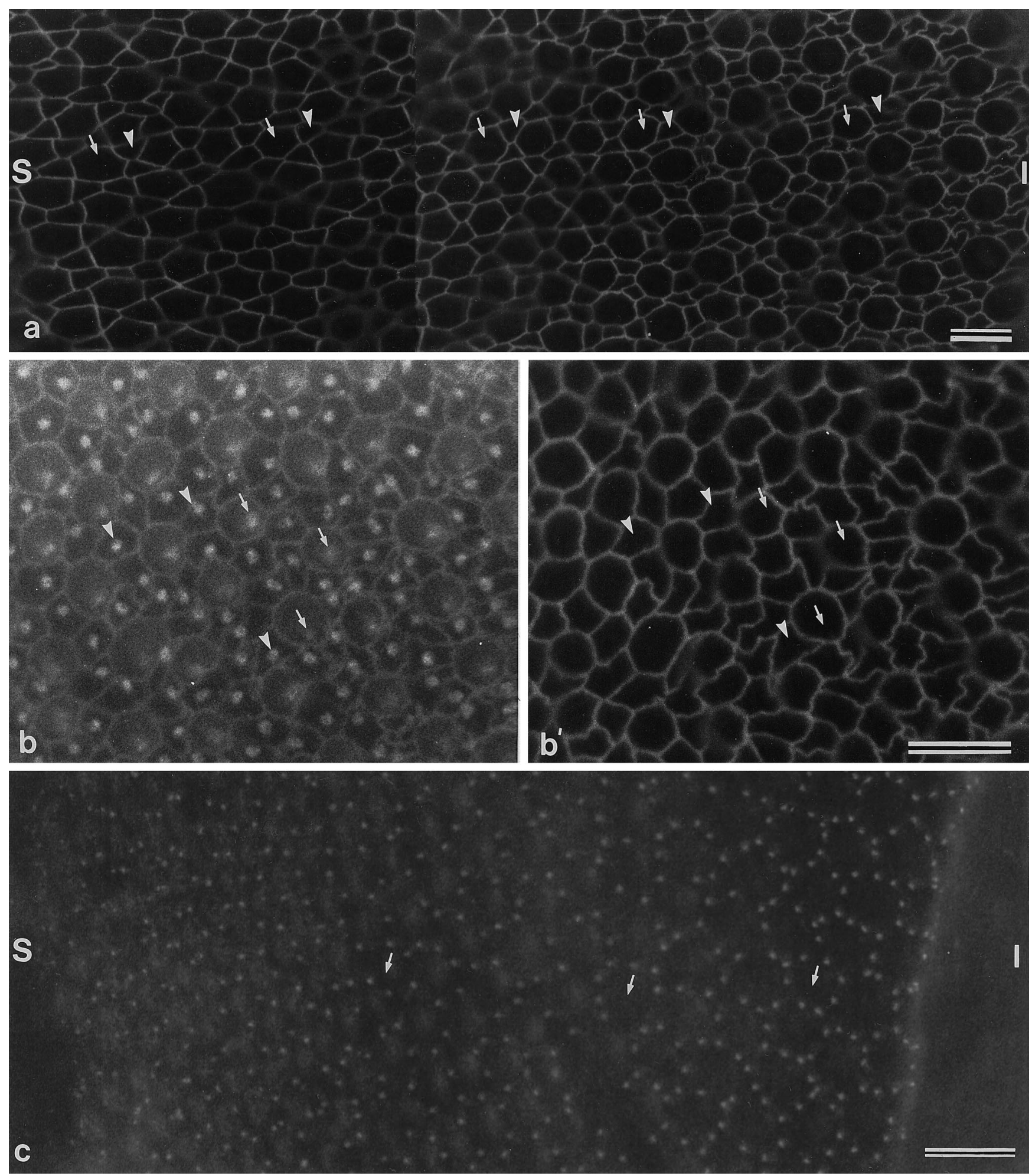

Figure 10. Double-labelling of cingulin and centrosome-associated material in papillar whole mounts. $a$, Photomontage of a medial region of the papilla at E12, spanning the entire width from the superior edge (left-hand side) to the inferior edge (right-hand side). Scale bar, $10 \mu \mathrm{m} . b, b^{\prime}, \mathrm{A}$ medial region of an E10 papilla that has been double-labeled with antibodies to the centrosome-associated material and cingulin $(b)$ and cingulin alone $\left(b^{\prime}\right)$. A single, discrete blob of staining can be seen within each cell (arrows, arrowheads) with the anti-centrosome-associated material antibody $(b)$. Scale bar, $10 \mu \mathrm{m}$. $c$, Anti-centrosome-associated material labeling in the proximal region of a posthatch papilla. The antibody does not recognize centrosome-associated material of mature hair cells, and each brightly stained blob represents a single supporting cell. Arrows point to the unlabeled hair cells between each ring of supporting cell centrosomes. Note the greater number of centrosomes in the rings at the inferior edge of the papilla. Scale bar, $20 \mu \mathrm{m}$. $S$, Superior edge; $I$, inferior edge; arrows, hair cells; arrowheads, supporting cells. 

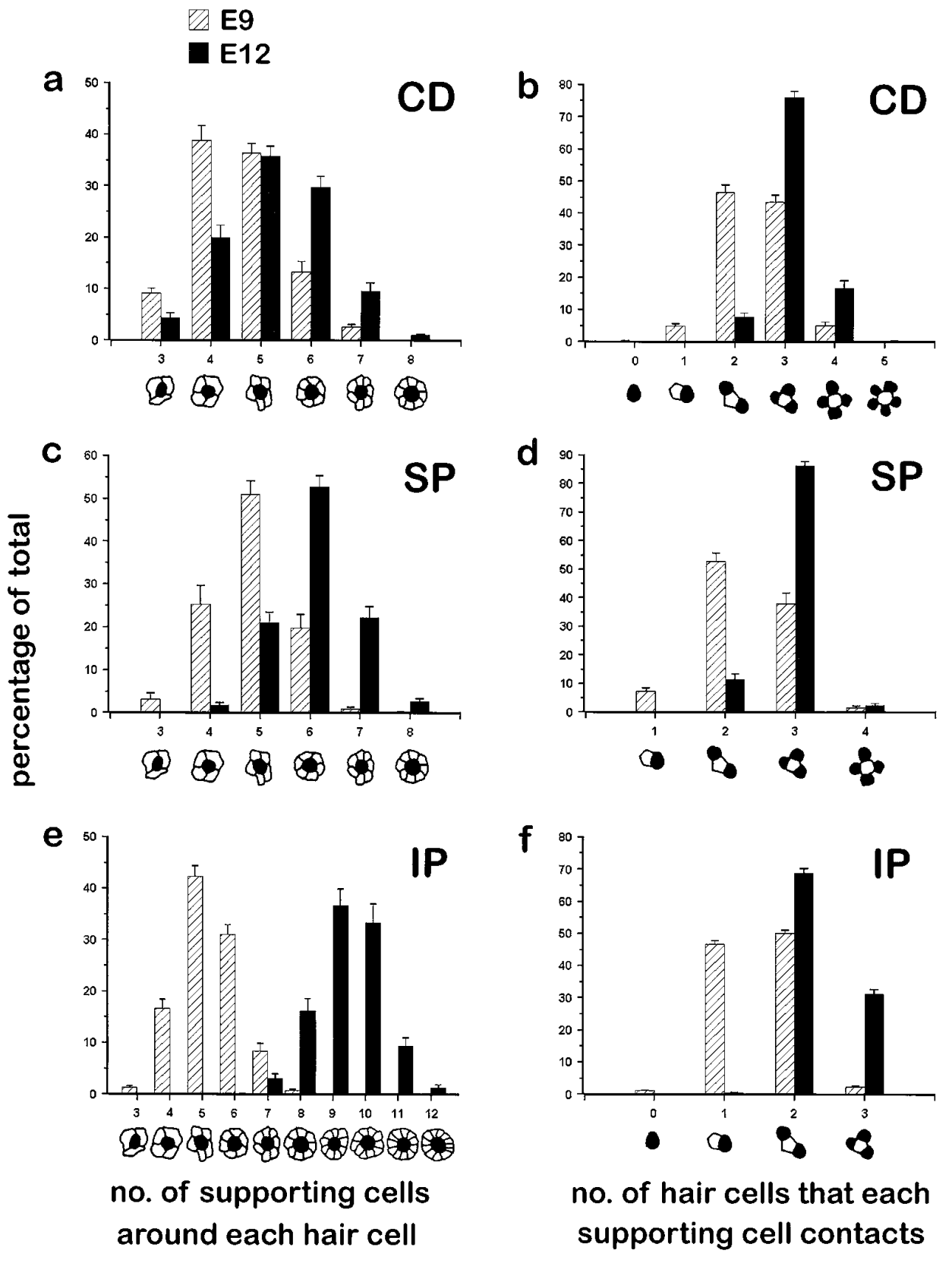

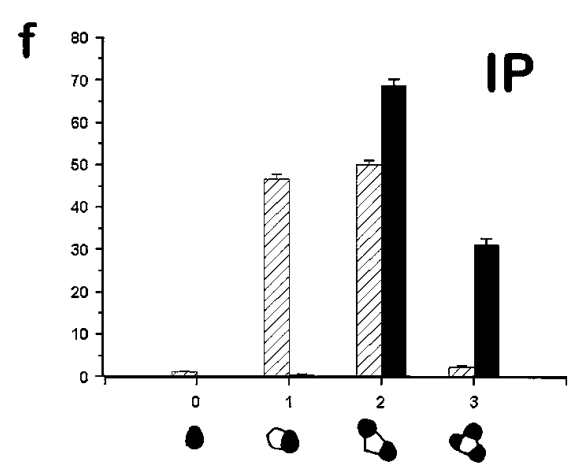

no. of hair cells that each supporting cell contacts
Figure 11. Graphs of changes in contacts between hair and supporting cells from E9 and E12. $a, c, e$ show changes in the number of supporting cells around each hair cell; $b$, $d$, $f$ show changes in the number of hair cells that each supporting cell contacts. Graphs are for the central-distal $(C D)$ region $(a, b)$, superior-proximal $(S P)$ region $(c, d)$, and inferior-proximal $(I P)$ region $(e, f)$. Error bars represent SEM.
Corwin, 1989) have indicated that all of the cells in these regions are postmitotic by E8.5. It is therefore unlikely that the increase in the number of supporting cells around each hair cell in these regions is caused by an increase in supporting cell numbers, and the simplest explanation for the observed increase in the average number of supporting cells around each hair cell is that the two cell types are rearranging with respect to one another, with the supporting cells acquiring more contacts with hair cells. This would be in agreement with the results, where an increase in the number of supporting cells surrounding each hair cell is accompanied by an increase in the number of hair cells that each supporting cell contacts.

In the inferior-proximal region, where the SHCs are located, the increases in the number of supporting cells around each hair cell and the number of hair cells that each supporting cell contacts are accompanied by a small but significant rise in the supporting cell/hair cell ratio. An increase in the ratio of sup- porting cells to hair cells in this region could result from an increase in supporting cells, a decrease in hair cells, or a combination of both processes. A decrease in hair cells in itself would not increase the number of supporting cells around each hair cell and would lead to a decrease in the number of hair cells that each supporting cell contacts. This is the opposite to what is observed. An increase in supporting cells would cause a rise in the number of supporting cells around each hair cell, but the small change observed in the supporting cell/hair cell ratio between E9 and E12 is not sufficient to account for the increase in the number of supporting cells seen around each hair cell between these two stages. For example, with a supporting cell/hair cell ratio of 3.56:1, a hypothetical field of 100 cells in the inferior-proximal region of the papilla at E9 would contain 78 supporting cells and 22 hair cells. The increase in the ratio to 3.9:1 observed by E12 would be equivalent to the addition of an extra seven to eight supporting cells to this field. If these were to contact three hair 
Table 2. Hair and supporting cell contact numbers at E9 and E12

\begin{tabular}{|c|c|c|c|c|c|c|}
\hline & \multicolumn{2}{|l|}{ Central-distal } & \multicolumn{2}{|c|}{ Superior-proximal } & \multicolumn{2}{|c|}{ Inferior-proximal } \\
\hline & E9 & E12 & E9 & $\mathrm{E} 12$ & E9 & E12 \\
\hline $\begin{array}{l}\text { Average number of supporting } \\
\text { cells around each hair cell }\end{array}$ & $\begin{array}{l}4.56( \pm 0.08) \\
(\mathrm{n}=17)\end{array}$ & $\begin{array}{l}5.23 *( \pm 0.09) \\
(\mathrm{n}=18)\end{array}$ & $\begin{array}{l}4.89( \pm 0.10) \\
(\mathrm{n}=19)\end{array}$ & $\begin{array}{l}6.03 *(0.06) \\
(\mathrm{n}=18)\end{array}$ & $\begin{array}{l}5.27( \pm 0.04) \\
(\mathrm{n}=28)\end{array}$ & $\begin{array}{l}9.33^{*}( \pm 0.09) \\
(\mathrm{n}=24)\end{array}$ \\
\hline $\begin{array}{l}\text { Average number of hair cells that } \\
\text { each supporting cell contacts }\end{array}$ & $\begin{array}{l}2.48( \pm 0.05) \\
(\mathrm{n}=17)\end{array}$ & $\begin{array}{l}3.07 *( \pm 0.05) \\
(\mathrm{n}=18)\end{array}$ & $\begin{array}{l}2.32( \pm 0.06) \\
(\mathrm{n}=19)\end{array}$ & $\begin{array}{l}2.91 *( \pm 0.02) \\
(\mathrm{n}=18)\end{array}$ & $\begin{array}{l}1.53( \pm 0.01) \\
(\mathrm{n}=28)\end{array}$ & $\begin{array}{l}2.31^{*}( \pm 0.02) \\
(\mathrm{n}=24)\end{array}$ \\
\hline
\end{tabular}

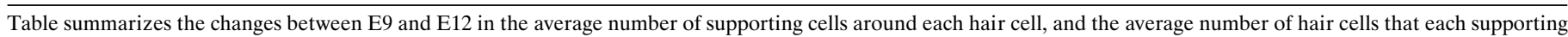

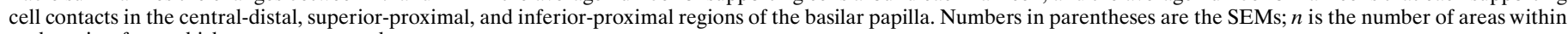
each region from which counts were made.

* Value is significantly different from corresponding E9 value; $p<0.0001$.

Table 3. Hair and supporting cell densities and ratios of the two cell types in each area at E9 and E12

\begin{tabular}{|c|c|c|c|c|c|c|}
\hline & \multicolumn{2}{|l|}{ Central-distal } & \multicolumn{2}{|c|}{ Superior-proximal } & \multicolumn{2}{|c|}{ Inferior-proximal } \\
\hline & E9 & E12 & E9 & E12 & E9 & E12 \\
\hline $\begin{array}{l}\text { Average number of supporting } \\
\text { cells per } 10,000 \mu \mathrm{m}^{2}\end{array}$ & $\begin{array}{l}677( \pm 23.4) \\
(\mathrm{n}=17)\end{array}$ & $\begin{array}{l}398( \pm 28.9) \\
(\mathrm{n}=18)\end{array}$ & $\begin{array}{l}446( \pm 19.4) \\
(\mathrm{n}=19)\end{array}$ & $\begin{array}{l}201( \pm 8.9) \\
(\mathrm{n}=18)\end{array}$ & $\begin{array}{l}545( \pm 20) \\
(\mathrm{n}=28)\end{array}$ & $\begin{array}{l}377( \pm 97) \\
(\mathrm{n}=24)\end{array}$ \\
\hline $\begin{array}{l}\text { Average number of hair cells per } \\
\qquad 10,000 \mu \mathrm{m}^{2}\end{array}$ & $\begin{array}{l}370( \pm 17.2) \\
(\mathrm{n}=17)\end{array}$ & $\begin{array}{l}241( \pm 22.2) \\
(\mathrm{n}=18)\end{array}$ & $\begin{array}{l}213( \pm 10.3) \\
(\mathrm{n}=19)\end{array}$ & $\begin{array}{l}94( \pm 4.5) \\
(\mathrm{n}=18)\end{array}$ & $\begin{array}{l}154( \pm 6.0) \\
(\mathrm{n}=28)\end{array}$ & $\begin{array}{l}97( \pm 4.5) \\
(\mathrm{n}=24)\end{array}$ \\
\hline $\begin{array}{l}\text { Average supporting cell to hair } \\
\text { cell ratios }\end{array}$ & $\begin{array}{l}1.85( \pm 0.05): 1 \\
(\mathrm{n}=17)\end{array}$ & $\begin{array}{l}1.71( \pm 0.05): 1^{a} \\
(\mathrm{n}=18)\end{array}$ & $\begin{array}{l}2.13( \pm 0.07): 1 \\
(\mathrm{n}=19)\end{array}$ & $\begin{array}{l}2.14( \pm 0.05): 1^{a} \\
(\mathrm{n}=18)\end{array}$ & $\begin{array}{l}3.56( \pm 0.05): 1 \\
(\mathrm{n}=28)\end{array}$ & $\begin{array}{l}3.90( \pm 0.07): 1^{*} \\
(\mathrm{n}=24)\end{array}$ \\
\hline
\end{tabular}

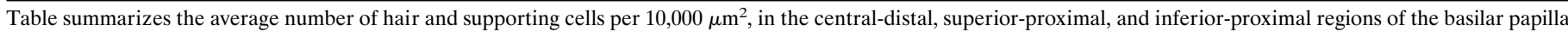

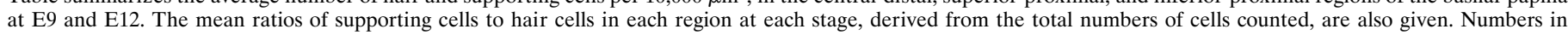
parentheses are the SEMs; $n$ is the number of areas within each region from which counts were made.

* Value is significantly different from corresponding E9 value; $p<0.001$.

${ }^{a}$ Value is not significantly different from E9 value; $p>0.05$

cells, which is the maximum observed in this region at E12, then there would be an extra 21-24 supporting cell-hair cell contacts, which would be equivalent to an increase of one extra supporting cell around each hair cell. The average number of supporting cells around each hair cell actually rises by more than four between E9 and E12 in the inferior-proximal region, indicating further that cell rearrangement must largely account for the observed increase. Although substantially more complex scenarios may be envisioned to account for the observed results (i.e., strategic addition of hair and supporting cells to the mosaic in the correct ratio), they may be difficult to orchestrate, and cell rearrangement seems to be the most plausible current explanation.

Movements of cells relative to one another are necessary for wound healing and many morphogenetic processes, such as gastrulation and formation of the neural tube. Although it was proposed initially that differential cell adhesion alone would not drive these movements and functions only to stabilize the most favorable contacts brought about by cells actively exploring their neighborhood (Graner, 1993), more recent mathematical models show that differential adhesion between cells is sufficient to explain many types of cell rearrangement observed in biological systems (Glazier and Graner 1993). The dramatic change in hair and supporting cell organization observed in the inferiorproximal region of the papilla between E9 and E12 is morphologically comparable to the way in which interommatidial cells reorganize to form single chains around each ommatidium during development of the Drosophila compound eye (Cagan and Ready, 1989), and it has been shown recently that this process involves a gene (irrecC-rst) encoding an adhesion molecule of the immunoglobulin superfamily (Reiter et al., 1996). Although the IrrecC-rst protein mediates homophilic adhesion in transfected cells (Schneider et al., 1995), it accumulates in interommatidial cells at their borders with primary pigment cells after its downregulation in this latter cell type and may therefore interact heterophilically with an as yet undiscovered ligand (Reiter et al., 1996). The changes observed in the organization of hair and supporting cells in the papilla may be brought about solely by differential adhesion through a mechanism similar to that involving IrrecC-rst in the Drosophila eye and could result from a heterotypic attraction between hair and supporting cells that is preferential to homotypic interactions between supporting cells. N-CAM and both Nand E-cadherin are expressed in the developing papilla (Richardson et al., 1987; Raphael et al., 1988), and whether any of these adhesion molecules or the closest known chicken homolog of IrrecC-rst, variously known as DM-GRASP, SC1, and BEN (Burns et al., 1991; Tanaka et al., 1991; Pourquie et al., 1992), are involved in this process remains to be determined experimentally.

\section{REFERENCES}

Artavanis-Tsakonas S, Matsuno K, Fortini ME (1995) Notch signaling. Science 268:225-232.

Austin CP, Feldman, DE, Ida JA, Cepko CL (1995) Vertebrate retinal ganglion cells are selected from competent progenitors by the action of Notch. Development 125:3637-2650.

Baker NE, Yu S-Y (1997) Proneural function of neurogenic genes in the developing Drosophila eye. Curr Biol 7:122-132.

Bartolami S, Goodyear R, Richardson G (1991) Appearance and distribution of the $275 \mathrm{kDa}$ hair-cell antigen during development of the avian inner ear. J Comp Neurol 314:777-788.

Burns FR, von Kannen S, Guy L, Raper JA, Kamholz J, Chang S (1991) DM-GRASP, a novel immunoglobulin superfamily axonal surface protein that supports neurite extension. Neuron 7:209-220. 
Cagan RL, Ready DF (1989) The emergence of order in the Drosophila pupal retina. Dev Biol 136:346-362.

Chitnis A, Henrique D, Lewis J, Ish-Horowicz D, Kintner C (1995) Primary neurogenesis in Xenopus embryos regulated by a homologue of the Drosophila neurogenic gene Delta. Nature 375:761-766.

Citi S, Sabanay H, Jakes R, Geiger B, Kendrick-Jones J (1988) Cingulin, a new peripheral component of tight junctions. Nature 333:272-276.

Collier JR, Monk NAM, Miani PK, Lewis JH (1996) Pattern formation by lateral inhibition with feedback: a mathematical model of DeltaNotch intercellular signalling. J Theor Biol 183:429-446.

Corwin JT, Jones JE, Katayama A, Kelley MW, Warchol ME (1991) Hair cell regeneration: the identification of progenitor cells, potential triggers and instructive cues. In: Regeneration of vertebrate sensory receptor cells (Bock R, Whelan J, eds) pp 103-119. New York: Wiley.

Cotanche DA (1987) Regeneration of hair cell stereociliary bundles in the chick cochlea following severe acoustic trauma. Hearing Res 30:181-196.

Cotanche DA, Sulik KK (1984) The development of the stereociliary bundles in the cochlea duct of chick embryos. Dev Brain Res 16:181-193.

Glazier JA, Graner F (1993) Simulation of the differential adhesion driven rearrangement of biological cells. Physical Rev E 47:2128-2154.

Goodyear R, Holley M, Richardson G (1995) Hair and supporting-cell differentiation during the development of the avian inner ear. J Comp Neurol 351:81-93.

Goodyear R, Killick R, Legan PK, Richardson G (1996) Distribution of $\beta$-tectorin mRNA in the early posthatch and developing avian inner ear. Hearing Res 96:167-178.

Graner F (1993) Can surface-adhesion drive cell-rearrangement. 1. Biological cell-sorting. J Theor Biol 164:455-476.

Henrique D, Adam J, Myat A, Chitnis A, Lewis J, Ish-Horowicz D (1995) Expression of a Delta homologue in prospective neurons in the chick. Nature 375:787-790.

Katayama A, Corwin JT (1989) Cell production in the chicken cochlea. J Comp Neurol 281:129-135.

Lewis J (1991) Rules for the production of sensory cells. In: Regeneration of vertebrate sensory receptor cells (Bock R, Whelan J, eds) pp 25-39. New York: Wiley.

Lewis J (1996) Neurogenic genes and vertebrate neurogenesis. Curr Opin Neurobiol 6:3-10.

Lindsell CE, Shawber CJ, Boulter J, Weinmaster N (1995) Jagged: a mammalian ligand that activates Notch 1. Cell 80:909-917.

Muskavitch MAT (1994) Delta-Notch signaling and Drosophila cell fate choice. Dev Biol 166:415-430.

Myat A, Henrique D, Ish-Horowicz D, Lewis J (1996) A chick homologue of Serrate, and its relationship with Notch and Delta homologues during central neurogenesis. Dev Biol 174:233-247.
Nye JS, Kopan R (1995) Vertebrate ligands for Notch. Curr Biol 5:966-969.

Oh S-H, Johnson R, Wu DK (1996) Differential expression of bone morphogenetic proteins in the developing vestibular and auditory sensory organs. J Neurosci 16:6463-6475.

Pourquie O, Corbel C, Le Caer J-P, Rossier J, Le Douarin NM (1992) $\mathrm{BEN}$, a surface glycoprotein of the immunoglobulin superfamily, is expressed in a variety of developing systems. Proc Natl Acad Sci USA 89:5261-5265.

Raphael Y, Volk T, Crossin KL, Edelman GM, Geiger B (1988) The modulation of cell adhesion molecule expression and intercellular junction formation in the developing avian inner ear. Dev Biol 128:222-235.

Reiter C, Schimansky T, Nie Z, Fischbach K (1996) Reorganization of membrane contacts prior to apoptosis in the Drosophila retina: the role of the IrreC-rst protein. Development 122:1931-1940.

Reynolds ES (1963) The use of lead citrate at high $\mathrm{pH}$ as an electron dense stain in electron microscopy. J Cell Biol 17:208-212.

Richardson GP, Crossin KL, Chuong C-M, Edelman GM (1987) Expression of cell adhesion molecules during embryonic induction. III. Development of the otic placode. Dev Biol 119:217-230.

Richardson GP, Bartolami S, Russell IJ (1990) Identification of a 275 $\mathrm{kDa}$ protein associated with the apical surfaces of sensory hair cells in the avian inner ear. J Cell Biol 110:1055-1066.

Schneider T, Reiter C, Eule E, Bader B, Lichte B, Nie Z, Schimansky T, Ramos RGP, Fischbach KF (1995) Neural recognition in the optic lobe of Drosophila: restricted expression of the IrreC-rst protein is required for normal axonal projections of columnar visual neurons. Neuron 15:259-271.

Simpson P (1995) The Notch connection. Nature 375:736-737.

Tanaka K, Smith CA (1978) Structure of the chicken's inner ear: SEM and TEM study. Am J Anat 153:251-272.

Tanaka H, Matsui T, Agata A, Tomura M, Kubota I, McFarland KC, Kohr B, Lee A, Phillips HS, Shelton DL (1991) Molecular cloning and expression of a novel adhesion molecule, SC1. Neuron 7:535-545.

Tepass U, Hartenstein V (1995) Neurogenic and proneural genes control cell fate specification in the Drosophila endoderm. Development 121:393-405.

Tilney LG, Saunders JC (1983) Actin-filaments, stereocilia, and haircells of the bird cochlea. 1. Length, number, width and distribution of stereocilia of each hair cell are related to the position of the hair cell on the cochlea. J Cell Biol 96:807-821.

Tilney LG, Tilney MS, Saunders JC, DeRosier DJ (1986) Actinfilaments, stereocilia, and hair cells of the bird cochlea. 3. The development and differentiation of hair-cells and stereocilia. Dev Biol 116: $100-118$. 